\title{
電着すず薄膜におけるウィスカー成長に対する内部応力の役割
}

\author{
上野 裕 美* 田中啓 介** $^{* *}$ \\ 來 海 博 央 $^{* *}$ 島 田大 輔*
}

\section{Role of Internal Stress in Whisker Growth of Electrodeposited Tin Thin Films}

\author{
by
}

\author{
Hiromi Unno ${ }^{*}$, Keisuke TanaKa ${ }^{* *}$, Hirohisa KimachI ${ }^{* *}$ and Daisuke Shimada ${ }^{*}$
}

Tin (Sn) thin films with various thicknesses were electrodeposited on $\mathrm{Cu}$ substrate with and without Ni undercoat. The change of the internal stress in Sn films was measured by the X-ray diffraction method. For the case of $2.2 \mu \mathrm{m}$ thick film without Ni undercoat, the initial internal stress was tensile and then gradually changed into compression. After $15 \mathrm{~h}$, the compressive stress became below $-25 \mathrm{MPa}$ and remained constant afterward. Filament-type whiskers were grown on the surface after the stress changed into compression. For Sn films thicker than $4.3 \mu$ m, the initial stress was compression and only nodule-type whiskers were grown on the surface. For the case of $2.2 \mu \mathrm{m}$ thick film with $\mathrm{Ni}$ undercoat, the stress was maintained in tension and no whisker was observed. For the cases of thicker films with and without Ni undercoat, the stress was compression around -30MPa just after deposition, and did not change with time. Nodule and mount-type whiskers were formed on the surface, but no filament-type whisker was observed. The compressive stress introduced by bending in $2.2 \mu \mathrm{m}$ thick film with $\mathrm{Ni}$ undercoat resulted in the formation of mounttype whisker. The postbake process induced the tensile stress in $2.2 \mu \mathrm{m}$ thick film and eliminated the formation of whiskers.

Key words : Tin whisker, Residual stress, Electrodeposited tin film, X-ray stress measurement, Ni undercoat, Postbake

\section{1 緒言}

1940 年代にすず (Sn) めっき層のウィスカーによる通 信機器の短絡障害が多発し，その対策として数％の鉛を 添加することで発生を抑制してきた.1)しかし RoHS 指令 に伴う鉛フリー化の結果として, ウィスカーが発生し故 障にいたるという事例が，スペースシャトル，原子力発 電所, 自動車などの電子機器において多発している.2. こ のため, 早急な対策が求められているが, ウィスカー成 長挙動の支配因子の解明は十分ではない.

Sn ウィスカーは表面に発生・成長する細長いひげ状の 結晶であり, めっき後数日から数年をおいて発生し, 直 径は約 $1 \mu \mathrm{m}$ で, 長さは数 $\mathrm{mm}$ 程度にまで成長する。この ウィスカー成長の駆動力として, めっき層内の圧縮応力が 挙げられている.3) 8)この圧縮応力は, めっき時に発生す る初期残留応力のほか, 使用中に基材の $\mathrm{Cu}$ と $\mathrm{Sn}$ との金 属間化合物 (IMC) が生成されることで導入される.3) 8) このため, Snめっき前に Niの下地めっきを行い金属間 化合物の生成を防ぐと, ウィスカーが成長しないとされ ている.5)また，めっき直後に $150^{\circ} \mathrm{C} て ゙ ~ 1 h$ 程度保持するポ ストベーク (postbake) 処理行うことでも, ウィスカーの 成長を防ぐことができるとされている.9 しかし，これま でめっき層の内部応力の測定例は少なく, ウィスカー成 長に及ぼす内部応力の影響に関しては不明な点が多い.

そこで本研究では, Sn ウィスカーの成長挙動と Snめつ
き層の内部応力の関係を明らかにするため, Sn めっき層 の内部応力の変化とウィスカーの成長挙動との関係を検 討した。内部応力の測定には, X 線応力測定を用いた。 さらに, Snめっき層内の微視組織観察も行い, 金属間化 合物の形成状況を観察した。めっき条件は， $\mathrm{Cu}$ 基板上 に下地めっき無しで Snめっきを行った場合と, Niの下 地めっきをした後にSnめっきを行った場合の 2 種類と し, Sn の膜厚の影響を検討するとともに，曲げによるひ ずみ負荷およびポストベーク処理後の内部応力の経時変 化についても検討した.

\section{$2 \cdot 1$ 電着試験片の作成}

基板は無酸素 $\mathrm{Cu}$ 板（C1020）を使用した。板厚は $1.2 \mathrm{~mm}$ で，面内の寸法は $10 \times 70 \mathrm{~mm}^{2}$ である，基板の表 面は耐水研磨紙\#2000 まで研磨した後, 基板の片面に絶 縁処理を行い, めっきは片面にのみ行った。また比較の ため, $\mathrm{Ni}$ 下地めっきをしない試験片と $\mathrm{Ni}$ 下地めっきを した試験片を作成した．Niめつきにはスルファミン酸普 通浴を使用した。めっき条件は平均電流密度を

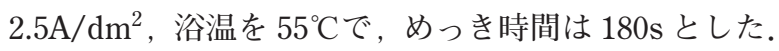
この時のめっき膜厚は $1.2 \mu \mathrm{m}$ である.

Sn めっきには有機スルホン酸浴を使用し, 光沢めっき を行った. $\mathrm{Sn}$ と $\mathrm{Cu}$ の合金めっきで $\mathrm{Cu}$ の含有量は 1.5 $w t \%$ である。以下簡単のために Sn めっきと称する。めっ

† 原稿受理 平成 22 年 8 月 4 日 Received Aug. 4, 2010 @ 2011 The Society of Materials Science, Japan

* 学生会員 名城大学大学院理工学研究科 ₹468-8502 名古屋市天白区塩釜口, Graduate School, of Sci. and Tech., Meijo Univ., Tempaku-ku, Nagoya, 468-8502

** 正 会員 名城大学理工学部機械システム工学科 †468-8502 名古屋市天白区塩釜口, Dept. Mechanical Eng., Meijo Univ., Tempaku-ku, Nagoya, 468-8502 
きの平均電流密度は $15 \mathrm{~A} / \mathrm{dm}^{2}$, 浴温を $20^{\circ} \mathrm{C}$ と, めつ き時間は 4 種類で，20，45，90，180s とした。各時間に 対するめっきの膜厚は $2.2,4.3,8.1,16.5 \mu \mathrm{m}$ である。

Table 1 にめっき試験片の条件をまとめる．試験片記 号として，下地めっき無しをNU (not undercoated) で， 下地めっき有りをU (undercoated) で表し, ハイフン後 に膜厚を表す。

\section{$2 \cdot 2$ 顕微鏡観察}

ウィスカーの発生までの時間を測定するため，デジタ ルマイクロスコープ（ソニック製 BS-D8000-T）を用いて 表面観察を行った。観察はめっき後 $2 \mathrm{~h}$ あるいは $10 \mathrm{~h}$ お きに行い，40h 経過まで行った。

ウィスカーの詳細な観察として，サーマル電界放出形 走査電子顕微鏡（SEM：日本電子製 JSM-7000FS）を使 用して SEM 像観察を行った。観察はめっき後 $200 \mathrm{~h}$ で， めっき面に対して $45^{\circ}$ 傾けた方向から行った.

$\mathrm{Sn}$ 膜内部の組織観察として, 集束イオンビーム (Focused ion beam: FIB) 装置（SII ナノテクノロジー製 SMI3050) を用いた SIM (Scanning ion microscope) 像 観察を行った。観察は，めっき表面の保護のため表面に カーボンを蒸着させ，Sn 膜の厚さ方向に断面加工した 後，めっき面に対して $60^{\circ}$ 傾けた方向から行った。

\section{$2 \cdot 3 \mathrm{X}$ 線応力測定}

$\mathrm{X}$ 線応力測定には，平行ビーム光学系を装着した $\mathrm{X}$ 線 回折装置（島津製作所製 XD-D1）を使用し， $\sin ^{2} \psi$ 法で 行った. 測定条件を Table 2 に示す. 応力測定には $\beta-S n$ の 312 面の回折を使用した．結晶は正方晶で格子定数 $\mathrm{a}=$ $0.5831 \mathrm{~nm}, \mathrm{c}=0.3182 \mathrm{~nm}$ (JCPDS card No. 4-673) から求め る. 回折角は $2 \theta=143.96^{\circ}$ である. 測定は並傾法で定時 計測 (FT) 法を用い $2 \theta=141^{\circ} \sim 147^{\circ}$ でスキャンした. 応力定数 $K$ は，付録に述べるように単結晶の弾性定数か

Table 1 Conditions of electrodeposition.

\begin{tabular}{c|cc}
\hline $\begin{array}{c}\text { Specimen } \\
\text { identification }\end{array}$ & $\begin{array}{c}\text { Ni undercoat } \\
\text { thickness }(\mu \mathrm{m}) *\end{array}$ & $\begin{array}{c}\text { Sn coat } \\
\text { thickness }(\mu \mathrm{m}) *\end{array}$ \\
\hline NU-2 & 0 & 2.2 \\
NU-4 & 0 & 4.3 \\
NU-8 & 0 & 8.1 \\
NU-16 & 0 & 16.5 \\
\hline U-2 & 1.2 & 2.2 \\
U-4 & 1.2 & 4.3 \\
U-8 & 1.2 & 8.1 \\
U-16 & 1.2 & 16.5 \\
\hline
\end{tabular}

* Film thickness was determined from SIM image of the cross section made by FIB.

Table 2 X-ray conditions for stress measurement

\begin{tabular}{c|c}
\hline Equipment & Shimadzu XD-D1 \\
\hline Optics & Parallel beam method \\
Characteristic X-ray & Cr-K $\alpha$ \\
Diffraction plane & 312 \\
Diffraction angle & $143.96 \mathrm{deg}$ \\
Filter & $\mathrm{V}$ \\
\hline Tube voltage & $40 \mathrm{kV}$ \\
Tube current & $30 \mathrm{~mA}$ \\
Divergent angle & $0.64 \mathrm{deg}$ \\
Step width & $0.05 \mathrm{deg}$ \\
Time constant & $2 \mathrm{~s}$ \\
\hline
\end{tabular}

ら求めた值 $K=-109 \mathrm{MPa} / \mathrm{deg}$ を使用した。 なお， Cr$\mathrm{K} \alpha$ 線の侵入深さは $\psi=0^{\circ}$ で約 $0.9 \mu \mathrm{m}$ である. ${ }^{10)}$

\section{3 実験結果および考察}

\section{$3 \cdot 1$ 表面観察}

$\mathrm{Sn}$ の膜厚が $2.2 \mu \mathrm{m}$ で下地が無い場合 (NU-2)，23h 後 にはウィスカーが観察された。一方同じ膜厚で下地がある 場合 (U-2)，200h 後もウィスカーは観察されず， $1.2 \mu \mathrm{m}$ の $\mathrm{Ni}$ 下地めっきがウィスカーの形成を抑制することが確 認された。なお，ウィスカーは狭義には単結晶の針状の結 晶を意味しているが，広義でのウィスカーの形態は，フィ ラメント型 (filament type), コラム型 (column type)，ノ ジュール型 (nodule type), およびマウント型 (mount type）に分類できる.4)ここでは，コラム型とノジュール型 とを区別せずノジュール型と称する．また，マウント型が 成長するとノジュール型になると考えられるが，直径が $2 \mu \mathrm{m}$ 以下かつ長さが $10 \mu \mathrm{m}$ 以上をフィラメント型，直径 および高さが $2 \mu \mathrm{m}$ 程度以下をマウント型，それ以上を， ジュール型とする．Fig. 1 に，NU-2 材のめっき後 $200 \mathrm{~h}$ で観察された代表的なウィスカーの SEM 像を示す。(a) がフィラメント型で，フィラメント型の頂上は平坦になっ ていた。一方，(b) はフィラメント型の近傍に形成されて いたノジュール型である。(c) は混合型で，ウィスカーが フィラメント型で形成された後に，ノジュール型に変わっ た例である。

Fig. 2 に, 下地無しで膜厚が $4 \mu \mathrm{m}$ 以上の NU-4 と NU16 の SEM 像を示す. (a) の NU-4 ではノジュール型であっ たが，(b) の NU-16ではこのほか，マウント型も認めら れた。 $\mathrm{Ni}$ 下地無しの場合でも膜厚が $4 \mu \mathrm{m}$ 以上になると， フィラメント型は認められず，ノジュール型とマウント 型であった。

下地めっきがあっても膜厚が大きくなるとウィスカー の発生が認められた. Fig. 3 は下地有りの場合であり， (a) の U-4 ではマウント型が主体で，(b) の U-16 では八 ジュール型も認められた。なお，U-8 は U-4 に近い形態 となった

以上の結果を Table 3 にまとめる. 表中の 2 列目のウィ スカー発生時間は, 各試験片に対して光学顕微鏡で初め てウィスカーが確認された時間である。ウィスカーの発 生はめっきから約 $10 \mathrm{~h}$ から $40 \mathrm{~h}$ 後に認められ，下地無し の場合はより短時間となる。表中の 3 列目にはSEM で 観察されたウィスカーの主な形態をまとめる。配線の短 絡にはフィラメント型のウィスカーの成長が特に危険で あると考えられるが，この形態は NU-2のみに観察され， 膜厚が厚くなるとフィラメント型は確認されなかった。

\section{$3 \cdot 2$ 内部応力の経時変化}

Snめっき膜の内部応力について, めっき直後からの経 時変化を測定した。応力測定には $\sin ^{2} \psi$ 法を用いたが， $\sin ^{2} \psi=0$ 〜 0.15 では回折ピークが得られなかったため, $\sin ^{2} \psi=0.2 \sim 0.7$ を 0.1 刻みした 6 点の結果を最小二乗 法で直線近似した. 6 点に対する直線性は良好であった。 傾きに応力定数 $K=-109 \mathrm{MPa} / \mathrm{deg}$ を掛けて内部応力を 算出した。ここで，応力測定方向は平板の長手方向であ るが，めっき膜の応力は等 2 軸応力状態であることを確 かめている. Fig. 4 に膜厚が $2.2 \mu \mathrm{m}$ ，および $16.5 \mu \mathrm{m}$ の測 
Table 3 Whisker initiation time and whisker type.

\begin{tabular}{c|cc}
\hline $\begin{array}{c}\text { Specimen } \\
\text { identification }\end{array}$ & $\begin{array}{c}\text { Whisker initiation } \\
\text { time (h) }\end{array}$ & Whisker type \\
\hline NU-2 & 23 & Filament, Nodule \\
NU-4 & 10 & Nodule \\
NU-8 & 20 & Nodule, Mount \\
NU-16 & 13 & Nodule, Mount \\
\hline U-2 & No & No Whisker \\
U-4 & 45 & Mount \\
U-8 & 45 & Mount \\
U-16 & 13 & Nodule, Mount \\
\hline
\end{tabular}
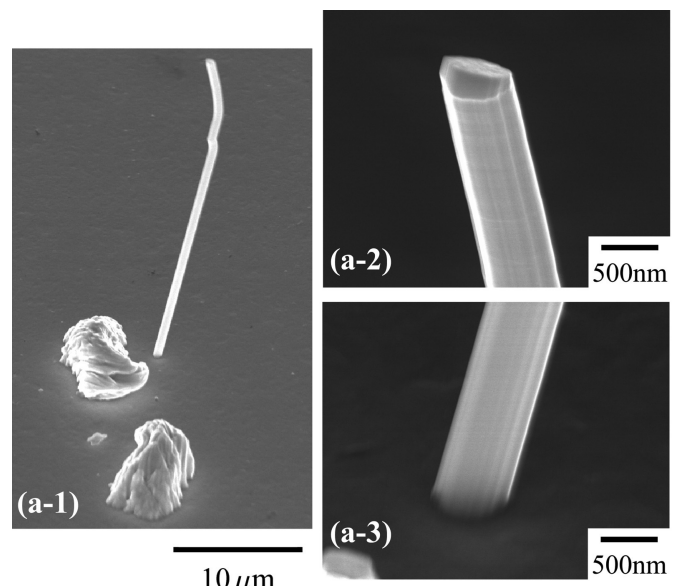

(a) Filament type

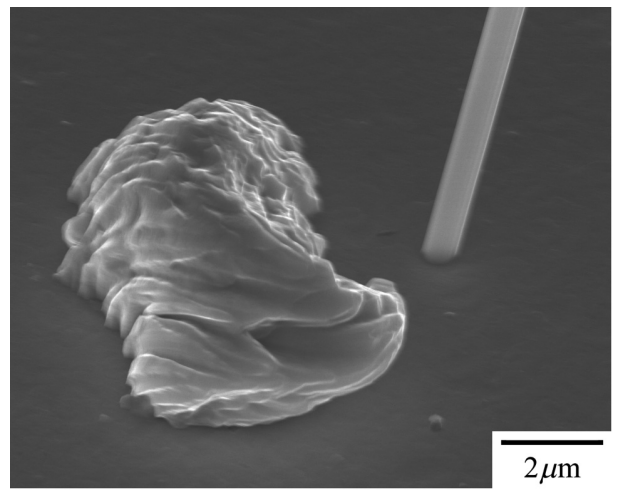

(b) Nodule type

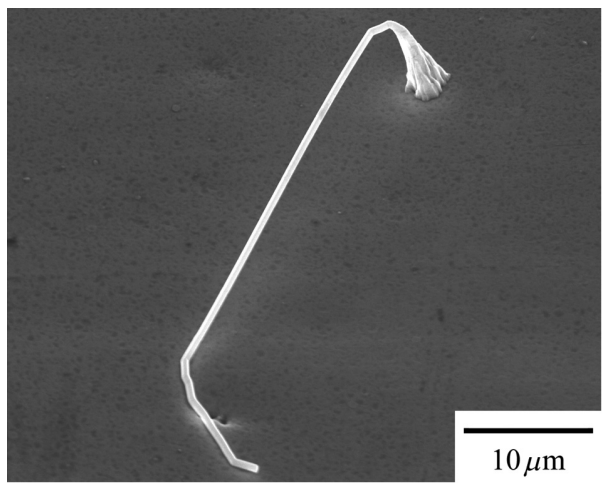

(c) Mixed type

Fig. 1 SEM images of NU-2 . (2.2 $\mu \mathrm{m}$ without undercoat)

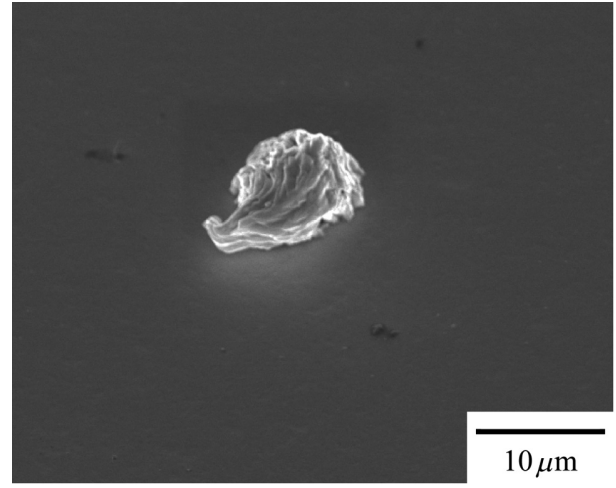

(a) NU-4 (4.3 $\mu \mathrm{m}$ without undercoat)
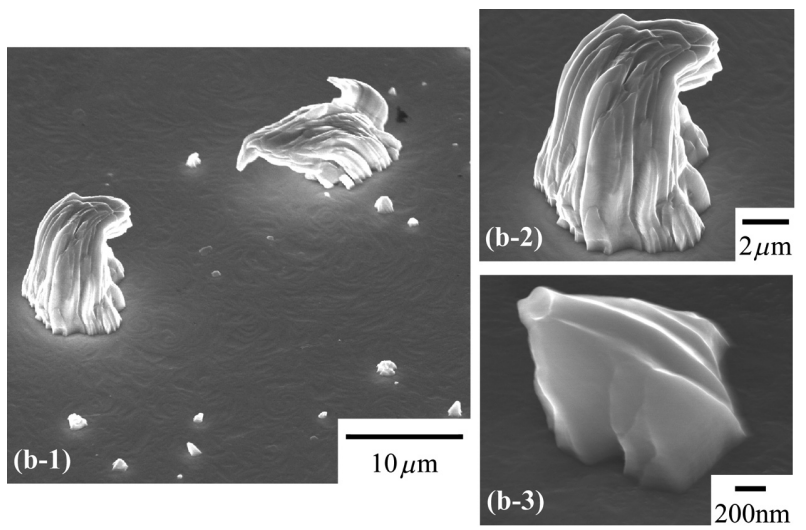

(b) NU-16 (16.5 $\mu \mathrm{m}$ without undercoat)

Fig. 2 SEM images of NU-4 and NU-16.

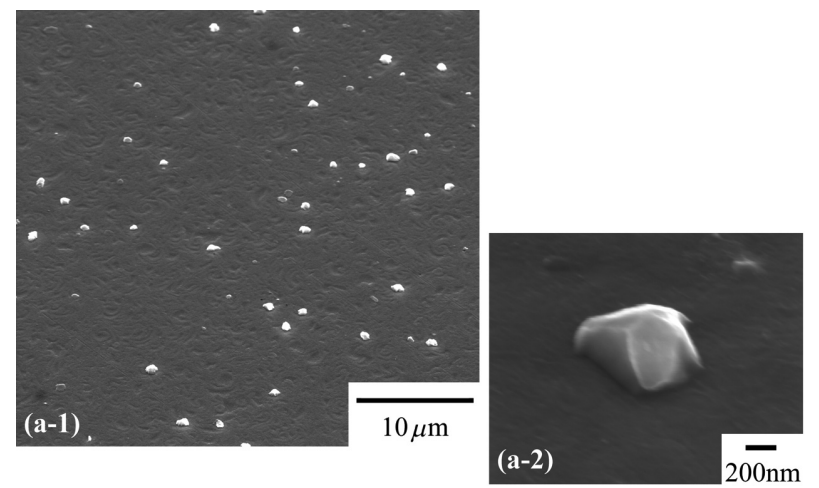

(a) U-4 $(4.3 \mu \mathrm{m}$ with undercoat $)$
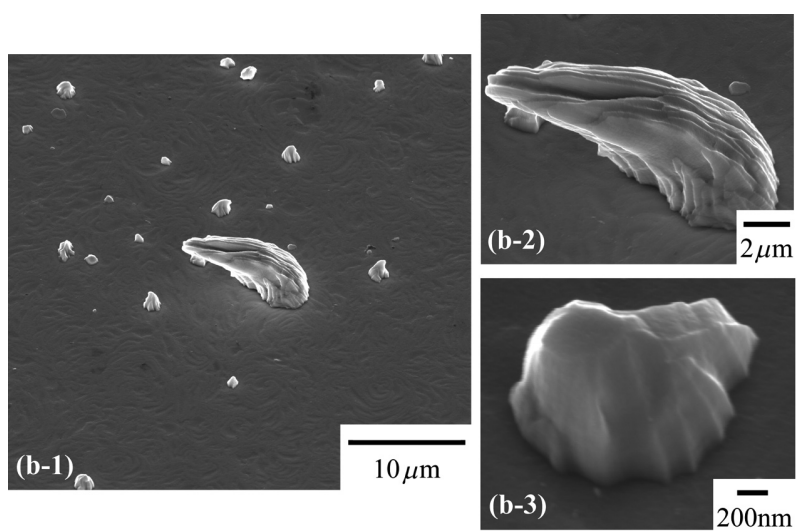

(b) U-16 (16.5 $\mu \mathrm{m}$ with undercoat)

Fig. 3 SEM images of U-4 and U-16. 
定結果を示す，横軸に経過時間，縦軸に内部応力をとっ た。 また，罒中には $\sin ^{2} \psi$ の $68.3 \%$ 信頼限界も示す．以 下, Table 3 に示したウィスカーの発生状況と対比させ ながら検討する.

$\mathrm{Sn}$ が $2.2 \mu \mathrm{m}$ で $\mathrm{Ni}$ 下地無しの場合 (NU-2), 初期に引 張りであった応力が経時的に圧縮側へ大きく変化し， $20 \mathrm{~h}$ 後には $25 \mathrm{MPa}$ 程度の圧縮となった。矢の後变化は緩や かになった。 なお， ウィスカーは $23 \mathrm{~h}$ 程度で確認された。 一方, $\mathrm{Ni}$ 下地有りの場合 (U-2), 初期の引張応力は時間 経過とともに減衰するが, 引張り側に留まり, ウィスカー は確認されなかった。 $\mathrm{Ni}$ 下地無しの場合には, $\mathrm{Sn}$ と $\mathrm{Cu}$ の界面にIMC が形成され，このため圧縮応力が導入さ れることが報告されており, 3) 8) 本研究においても後述の ように金属間化合物の形成が確認された。これに対して $\mathrm{Ni}$ 下地有りの場合は，金属間化合物の形成が抑制される ため, 初期の引張内部応力は圧縮側に変化せず, ウィス カーが発生しないと考えられる。な打，時間とともに Sn の引張応力が減衰するのはクリープ変形による応力緩和 と考えられる。

一方, Sn が $16.5 \mu \mathrm{m}$ の場合 (U-16, NU-16) は, Ni 下 地の有無に関わらずめっき直後の応力が-30MPa 程度の 圧縮側にあり，ほとんど変化しなかった。 また，ウィス カーの発生は $\mathrm{Ni}$ 下地の有無によらず $13 \mathrm{~h}$ 程度であった。 このことは，下地めっきをしても膜厚が大きくなると， $\mathrm{Sn}$ 層の内部応力が圧縮となり, ウィスカーの発生につな がることを意味する。

次に, 膜厚が異なった場合について同様の実駼を行つ た。この場合, 残留応力の変化がそれほど急激ではない

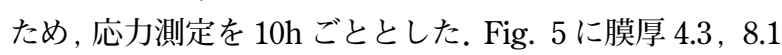
$\mu \mathrm{m}$ の内部応力の変化を示す. Sn が $8.1 \mu \mathrm{m}$ の場合 (U-8, NU-8) は, Ni の有無によらず, 初期から-30MPa 付近 にあり, 膜厚が $16.5 \mu \mathrm{m}$ の場合と同様に応力の変化は少 なかった。しかし, ウィスカー発生時間は少し長くなり, $\mathrm{Ni}$ 無しで 20h, Ni 有りで $45 \mathrm{~h}$ となった。一方, Sn が $4.3 \mu \mathrm{m}$ の場合 (U-4, NU-4) は, Ni の有無によらず-20MPa 程度の圧縮側であり, その後, $\mathrm{Ni}$ 有の場合 (U-4) には, 圧縮応力が減少し，20h でほぼ零となった。これに対し $\mathrm{Ni}$ 無しの場合 (NU-4) は, $-20 \sim-30 \mathrm{MPa}$ 程度であまり 変化しない。 ウィスカー発生時間は少し長くなり, $\mathrm{Ni}$ 無 しで $10 \mathrm{~h}, \mathrm{Ni}$ 有りで $45 \mathrm{~h}$ となったが, 形態はマウント型 で，大きくは成長しなかった.

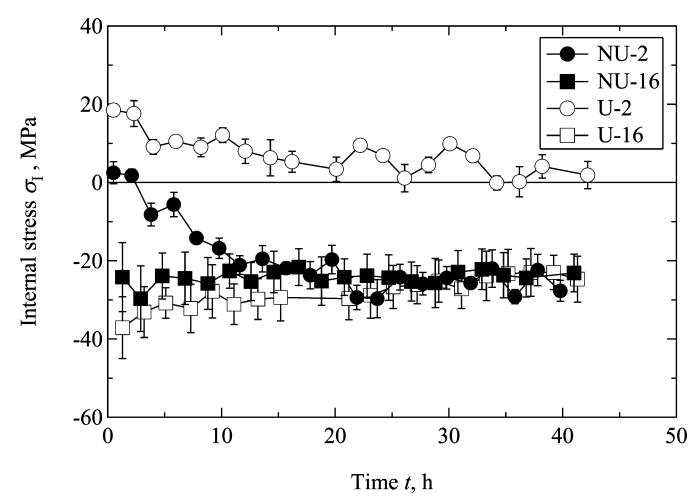

Fig. 4 Change of internal stress in Sn film with time for specimens with thicknesses of $2.2 \mu \mathrm{m}, 16.5 \mu \mathrm{m}$.

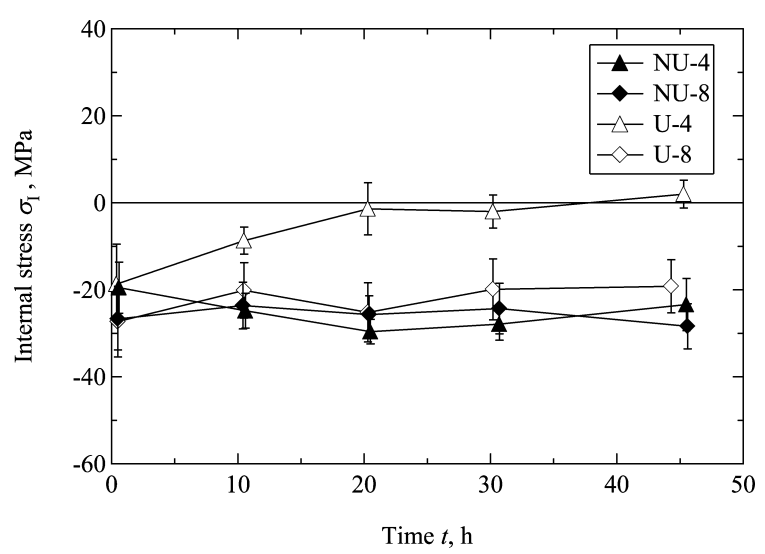

Fig. 5 Change of internal stress in Sn film with time for specimens with thicknesses of $4.3 \mu \mathrm{m}, 8.1 \mu \mathrm{m}$.

めっき直後の残留応力は, Sn 膜厚さが $2.2 \mu \mathrm{m}$ と $4.3 \mu \mathrm{m}$ では大きく異なった。 ウィスカーの形成の有無は, 圧縮内部応力によって決まって抲り, $-20 \mathrm{MPa}$ が $10 \mathrm{~h}$ 程 度存在するとウィスカーの発生をもたらすものと結論さ れる。しかし, 膜厚 $2.2 \mu \mathrm{m}$ の場合以外はフィラメント型 のウィスカーは形成されず，ウィスカーの形態には内部 応力と時間だけではなく, 内部応力の時間に対する変化 挙動あるいはSnの結晶配向性などの影響も考えられ，今 後の検討が必要である.

\section{$3 \cdot 3$ 内部組織観察}

$\mathrm{Sn}$ 膜厚が $2.2 \mu \mathrm{m}$ の試験片 (NU-2, U-2) のめっき層内 のSIM 像を，Fig. 6，7 に爷机ぞれ示す．ただし，(a)は めっき直後，(b)は $45 \mathrm{~h}$ 後である。なお， SIM像におけ る組成コントラストは原子番号が小さいほど明るくなる ため, Sn が最も暗く, Cu が最も明るく観察される.

Fig. 6 の NU-2 のめっき直後の断面では, Sn 粒界に 沿って $\mathrm{Sn} と \mathrm{Cu}$ の中間色の層が確認される。これは $\mathrm{Sn}$ $\mathrm{Cu}$ 合金中の $\mathrm{Cu}$ とで形成された IMC と考えられる。室 温で形成される $\mathrm{IMC}$ は $\mathrm{Cu}_{6} \mathrm{Sn}_{5}$ とされている.3) 8) めっき 後 $45 \mathrm{~h}$ の断面に打いては, $1 \mathrm{~h}$ と比較してこの中間色が占 める割合が増加した。

Fig. 7 の-2 に扔いても，NU-2 と同様にSn 粒界に 沿って中間色の層が確認された。しかし $45 \mathrm{~h} の$ の断面にお いてもこの層は増加して打らず， $\mathrm{Ni}$ 下地によって基板か らの Cu の拡散が抑制されているものと考えられる.

そこで，さらに長時間置いた試験片について，断面観 察を行った. 試験片条件はU-8 およびNU-8 である. NU-8 の SIM 像を Fig. 8 (a)に, U-8 を Fig. 8 (b)に示す. U-8 はめっき後 $3700 \mathrm{~h}, \mathrm{NU}-8$ はめっき後 $2600 \mathrm{~h}$ 経過したも のである. NU-8では基板とすずとの界面に IMC が形成 された層が確認できる。この層は特に基板の $\mathrm{Cu}$ との界 面近傍に打いての増加が顕著であった。一方 U-8 では, めっき後の経過時間が長いにもかかわらず， Ni との界面 に拈いて IMC 形成量が少ない。これは，Ni 下地により 基板からの $\mathrm{Cu}$ の拡散が阻害され，IMC の形成が阻止さ れたと考えられる．また，Sn粒界での IMC の形成量は NU-8 と比較して大きな差は無い.このことからも, Sn 粒界部分の IMC は合金中の $\mathrm{Sn}$ と基板の $\mathrm{Cu}$ とにより形 成されたものであると考えられる。 


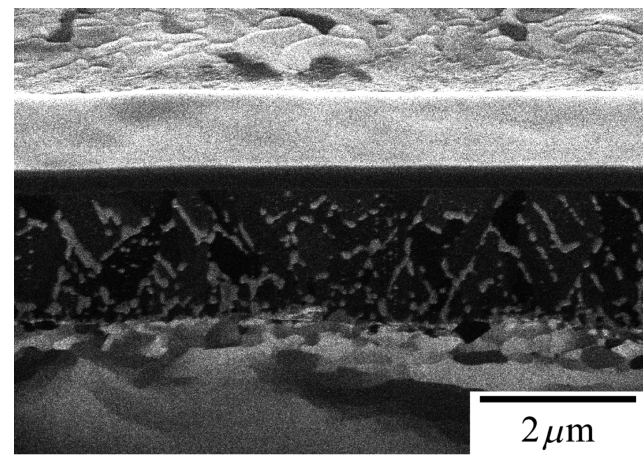

(a) $1 \mathrm{~h}$

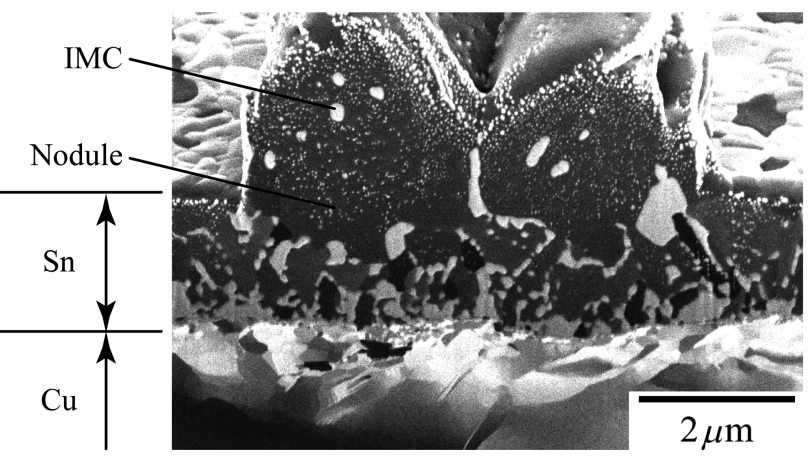

(b) $45 \mathrm{~h}$

Fig. 6 SIM images of NU-2 . (2.2 $\mu \mathrm{m}$ without undercoat)

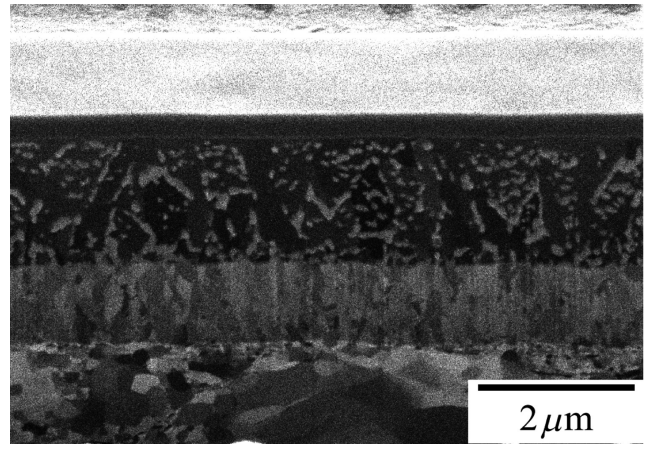

(a) $1 \mathrm{~h}$

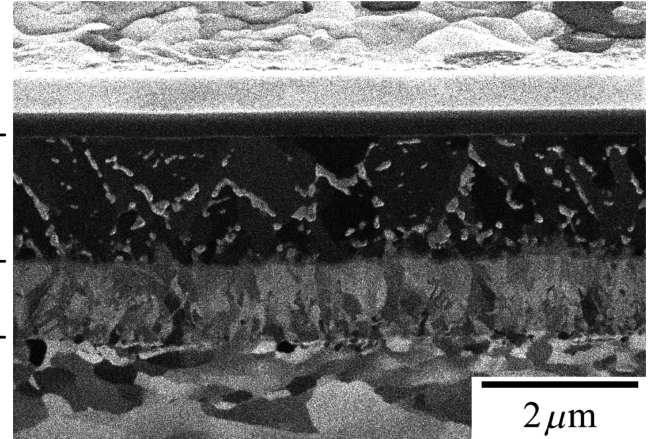

(b) $45 \mathrm{~h}$

Fig. 7 SIM images of U-2 . (2.2 $\mu \mathrm{m}$ with undercoat)

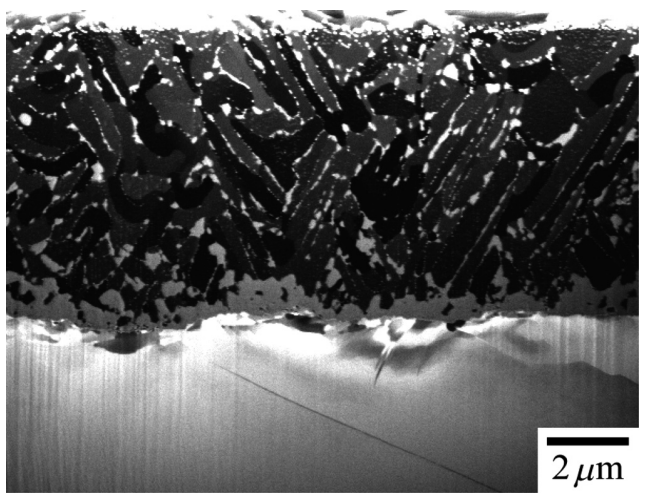

(a) NU-8 ( $8.1 \mu \mathrm{m}$ without undercoat), $2600 \mathrm{~h}$

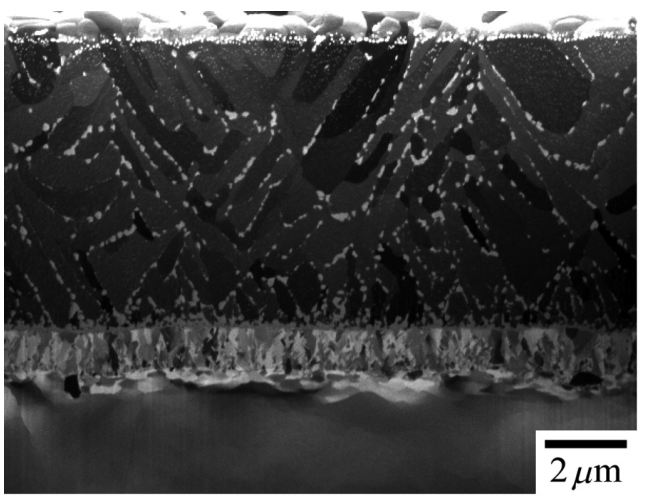

(b) U-8 (8.1 $\mu \mathrm{m}$ with undercoat), $3700 \mathrm{~h}$

Fig. 8 SIM images of NU-8, U-8 after long time elapsed.

\section{$3 \cdot 4$ 曲げ後の Sn 内部応カとウィスカー形成}

$\mathrm{Ni}$ 下地めっきが有り, Sn 膜厚が $2.2 \mu \mathrm{m}$ の場合 (U-2), 内部応力は引張りで, ウィスカーは発生しなかった。 そ こで, 外部から加えた圧縮応力の影響を検討するため, 次の二つの方法で圧縮応力を加えた。 まず，めっき面を 凸側にして 4 点曲げを行い，その後解放してスプリング バックによりめっき層内に压縮残留応力を導入した。こ れをU-2-RS (residual stress) 試験と称する.もう一方 は，めっき面を回側にして負荷応力が圧縮となるように 4 点曲げを行い保持した。これを，U-2-AS (applied stress）試験と称する. 曲げを加えた場合, 膜内の応力 は等 2 軸ではないが以下では長手方向の応力を測定した.
U-2-RS では，めっきをしていない面にひずみゲージを 貼り付け，めっき面を凸側にしてひずみ $0.3 \%$ まで 4 点曲 げを行い除荷した。このときの Snの内部応力の時間的 変化を Fig. 9 に示す. 初期の引張応力から負荷により引 張りが $37 \mathrm{MPa}$ まで増大し, 除荷後に-15MPa の圧縮応 力が残留した。 その後, 内部応力は時間とともに減衰し, 除荷後約 $15 \mathrm{~h}$ でほぼ零となった。この場合, めっきから $200 \mathrm{~h}$ 後もウィスカーの発生は観察されなかった. Fig. 5 に示した U-4 と比較すると, 圧縮応力がやや小さく減衰 が早いためにウィスカーが形成されなかったものと考え られる。

次にU-2-AS では，めっき面を凹側にして，ひずみ $0.3 \%$ 
まで4 点曲げを行いそのまま保持した，内部応力の時間 的変化を Fig. 10 に示す. 内部応力は， 4 点曲げにより -60MPa の圧縮応力が導入されたが，時間とともに急激 に減衰し $30 \mathrm{~h}$ ほどでほぼ零となった。この場合, U-2-RS とは異なりめっき後 $45 \mathrm{~h}$ でマウント型のウィスカーが多 数確認された。ただし、フィラメント型は確認されなかっ た．このことから，高い圧縮応力が $2 \sim 3 \mathrm{~h}$ 作用するこ とによってもウィスカーが発生すると考えられる。しか し，ウィスカー形態を決める要因については更なる検討 が必要である.

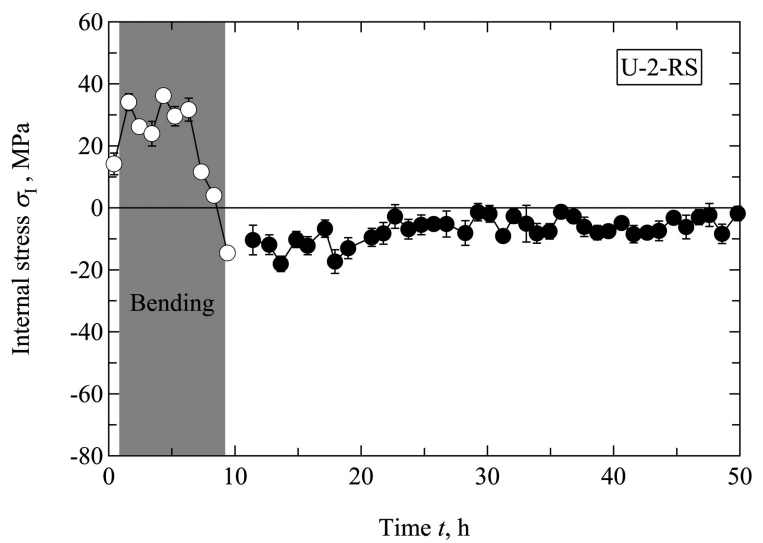

Fig. 9 Change of internal stress with time for U-2-RS. ( $2.2 u \mathrm{~m}$ with undercoat)

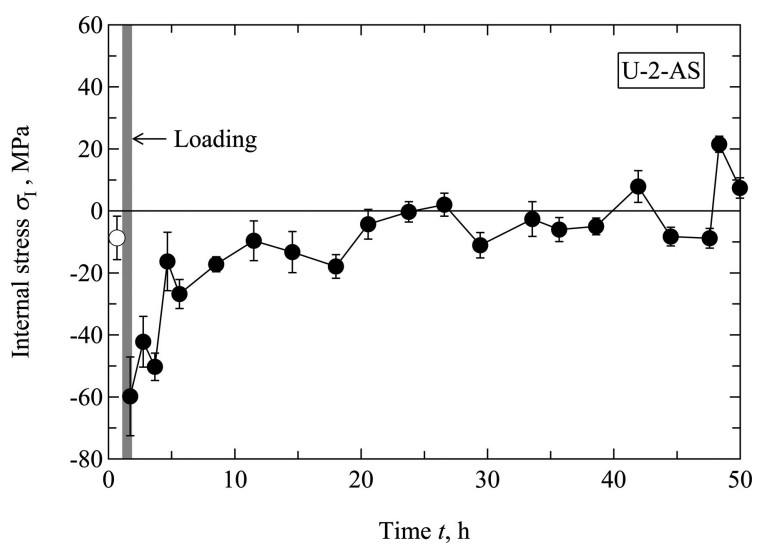

Fig. 10 Change of internal stress with time for U-2-AS. ( $2.2 \mu \mathrm{m}$ with undercoat)

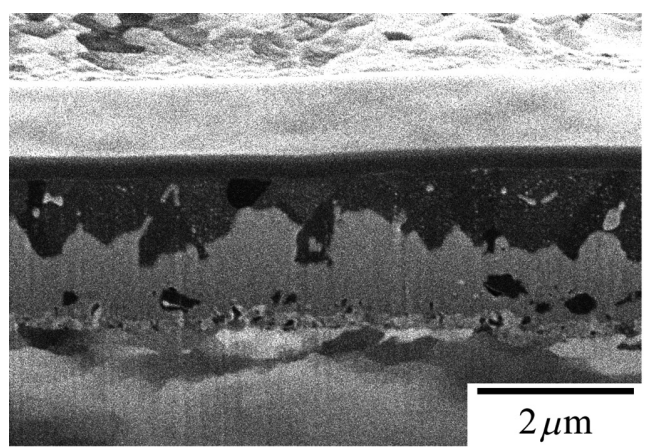

(a) $2 \mathrm{~h}$

\section{$3 \cdot 5$ ポストベーク処理後の Sn 内部応カとウィスカー 形成}

$\mathrm{Ni}$ 下地めっきが無い場合では，内部応力が圧縮にな り，多数のウィスカーが発生した，そこで，ウィスカー の発生防止に有効と考えられているポストベーク处理を 施した場合について検討した。試験片には，Ni下地めっ き無しの NU-2 打よびNU-16 を使用し，それでれめっき 直後に応力測定を行ってから， $150^{\circ} \mathrm{C} て ゙ ~ 1 \mathrm{~h}$ 加熱するポス トベーク処理を行った。この場合膜内の応力は等 2 軸で あった。

めっき直後からの Sn の内部応力の変化を Fig. 11 に示 す.めっき直後にはどちらも残留応力が圧縮にあったが， ポストベーク処理後は約 $30 \mathrm{MPa}$ の引張りに変化し，元 の後も引張りに留まった。この引張応力は, IMC の形成 あるいは $\mathrm{Sn}$ と基板の $\mathrm{Cu}$ との熱膨張係数の違いにより導 入されたものと考えられる.

$\mathrm{Sn}$ が $2.2 \mu \mathrm{m}$ の場合，ウィスカーは発生しなかった。し かし, Sn が $16.5 \mu \mathrm{m}$ の場合にはマウント型のウィスカー

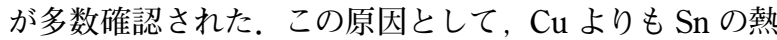
膨張係数が高いため，ポストベークの昇温中に Sn に大 きな圧縮応力が作用したためと考えられる。なおべーク 中の応力は測定されていない.

NU-2-PB のポストベーク処理直後の断面を Fig. 12 (a) に, めっき後 45h の断面を Fig. 12 (b) に示す. NU-2 の 場合とは異なり，ポストベーク処理によりすでに基板と の界面に厚い IMC 層が形成されて打り，45h 後もあまり

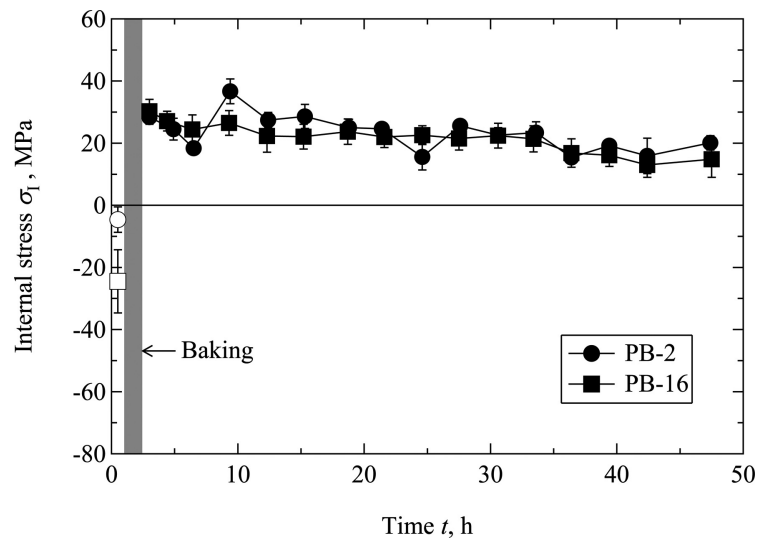

Fig. 11 Change of internal stress with time for NU-2-PB, NU-16-PB.

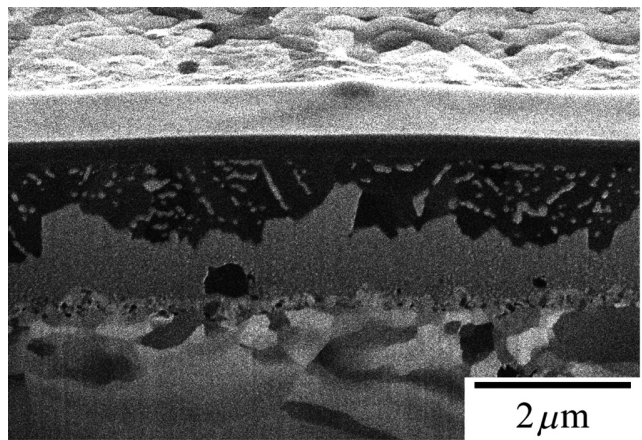

(b) $45 \mathrm{~h}$

Fig. 12 SIM images of NU-2-PB. (2.2 $\mu$ m without undercoat, Postbaked) 
変化が無い.このポストベークにより形成される IMC は $\operatorname{Kim} ら^{9)}$ によると $\mathrm{Cu}_{3} \mathrm{Sn}$ あるいは $\eta-\mathrm{Cu}_{6.26} \mathrm{Sn}_{5}$ であり，引 張応力の原因になるとされているが, 今後の検討が必要 である。

\section{4 結 言}

$\mathrm{Cu}$ 基板に $\mathrm{Ni}$ 下地を施した場合と施さない場合につい て種々の膜厚の Sn をめっき後, X 線によりめっき層の内 部応力測定を行い, ウィスカーの成長挙動との関係を検 討した。得られた結果を以下にまとめる.

(1) $\mathrm{Ni}$ 下地無しの場合には, いずれの膜厚において もウィスカーが発生した. 膜厚 $2.2 \mu \mathrm{m}$ の場合には, フィ ラメント型が多数観察されたが, 膜厚が $4 \mu \mathrm{m}$ 以上では主 としてノジュール型であった.

（2） $\mathrm{Ni}$ 下地有りの場合には, 膜厚が $2.2 \mu \mathrm{m}$ ではウィ スカーの発生は認められず, 膜厚が $4 \mu \mathrm{m}$ 以上では, ノ ジュール型あるいはマウント型が形成され，フィラメン 卜型は認められなかった。

（3） $\mathrm{Ni}$ 下地無しの場合，膜厚 $2.2 \mu \mathrm{m}$ のめっき層内の 応力はめっき直後の引張りから時間とともに減少して, $40 \mathrm{~h}$ 以上で-25MPa 程度の圧縮残留応力が保持された。 膜厚が $8 \mu \mathrm{m}$ 以上では，めっき直後から-30MPa 程度の圧 縮にあり, ほとんど変化しなかった。

（4） $\mathrm{Ni}$ 下地有りの場合, 膜厚が $2.2 \mu \mathrm{m}$ の $\mathrm{Sn}$ 層内の 応力はめっき直後の引張りから時間とともに減少し零に 近づいた。一方，膜厚が $4 \mu \mathrm{m}$ 以上になると，めっき直後 に内部応力は圧縮となり, 時間とともに徐々に零へと減 少した。

（5） $\mathrm{Ni}$ 下地有りの膜厚が $2.2 \mu \mathrm{m}$ の試験片に対して, 塑性曲げにより圧縮応力を導入した場合, ウィスカーは 形成されなかったが，約-60MPa の圧縮曲げ応力を負荷 した場合には，マウント型のウィスカーが発生した.

(6) $\mathrm{Ni}$ 下地無しの $2.2 \mu \mathrm{m}, 16.5 \mu \mathrm{m}$ の膜厚に対してポ ストベーク処理を行うと内部応力は引張りとなり，その 後の保持ではあまり変化しなかった. $2.2 \mu \mathrm{m}$ の場合には ウィスカーは形成されなかった。

\section{付録 $\mathbf{S n}$ の $\mathbf{X}$ 線応力定数}

$\mathrm{X}$ 線応力測定に必要な多結晶の $\mathrm{X}$ 線的弾性定数を単結 晶の弾性定数より算出した。 $\beta$-Sn の結晶系は正方晶であ り，独立な弾性コンプライアンスは， $s_{11}, s_{12}, s_{13}, s_{33}$, $s_{44}, s_{66}$ である. House 等によって共振法を用いた温度 93 ～468K に打ける測定結果が報告されている. ${ }^{11)} そ の$ 温 度変化に対するデータを使用して室温 $293 \mathrm{~K}$ における弾 性定数を求め Table 4 に示す。この值を使用して, Voigt モデル执よびReuss モデルに打ける $(1+v) / E$ を算出し

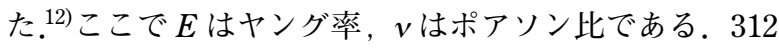
回折に対してそれぞれ $(1+v) / E=25.342 \mathrm{TPa}^{-1}$ および $26.897 \mathrm{TPa}^{-1}$ となった. これらの值の平均值 $26.120 \mathrm{TPa}^{-1}$ を次式に代入して, 応力定数 $K=-109 \mathrm{MPa} / \mathrm{deg}$ を算出 した.

$$
K=-\frac{E}{2(1+v)} \cdot \frac{\pi}{180} \cdot \cot \theta_{0}
$$

Table 4 Elastic constants of $\beta$-Sn single crystal at 293K. ( $s$-values in units $\mathrm{TPa}^{-1} ; c$-values in units $\mathrm{GPa}$ )

\begin{tabular}{cccccc}
\hline$s_{11}$ & $s_{12}$ & $s_{13}$ & $s_{33}$ & $s_{44}$ & $s_{66}$ \\
\hline 42.3 & -31.8 & 4.9 & 15 & 45.8 & 43.1 \\
\hline$c_{11}$ & $c_{12}$ & $c_{13}$ & $c_{33}$ & $c_{44}$ & $c_{66}$ \\
\hline 74.67 & 61.19 & 43.98 & 95.21 & 21.83 & 23.19 \\
\hline
\end{tabular}

\section{参 考 文 献}

1) G. T. Galyon, "A history of tin whisker theory : 1946 to 2004”, SMTAI International Conference, September 26-30, 2004 (Chicago, IL).

2 ) K. Suganuma, "History of tin whisker electronics failures", Function \& Materials, Vol.28, Issue 9, pp.5-12 (2008).

$3)$ B. Z. Lee and D. N. Lee, "Spontaneous growth mechanism of tin whiskers”, Acta Materialia, Vol.46, No.10, pp.3701-3714 (1998).

4 ) C. Xu, Y. Zahng, C. Fan and J. Abys, "Understanding whisker phenomenon : driving force for whisker formation”, Circuit Tree Magazine, pp.94-105 (2002).

5 ) S. Sakuyama and M. Kutami, "Substitute materials for complete elimination of hazardous substances - study of whisker growth on lead-free plating”, Fujitsu Scientific and Technical Journal, Vol.41, No.2, pp.217-224 (2005).

6 ) K. Tsuji, "Growth mechanism of tin whisker", Journal of the Surface Finishing Society of Japan, Vol.58, pp.406-411 (2007).

7 ) K. S. Kim, C. H. Yu, S. W. Han, K. C. Yang and J. H. Kim, "Investigation of relation between intermetallic and tin whisker growths under ambient condition”, Microelectronics Reliability, Vol.48, No.1, pp.111-118 (2008).

$8)$ M. Sobiech, U. Welzel, E. J. Mittemeijer, W. Hügel and A. Seekamp, "Driving force for Sn whisker growth in the system Cu-Sn”, Applied Physics Letters, Vol.93, Issue 1, 011906 (2008).

9) K. S. Kim, J. H. Kim and S. W. Han, "The effect of postbake treatment on whisker growth under high temperature and humidity conditions on tin-plated $\mathrm{Cu}$ substrates”, Materials Letters, Vol.62, No.12-13, pp.1867-1870 (2008).

10) K. Tanaka, K. Suzuki and Y. Akiniwa, "Evaluation of residual stresses by X-ray diffraction”, pp.77-78, pp.125-127 (2006) Yokendo.

11) D. G. House and E. V. Vernon, "Determination of the elastic moduli of tin single crystals, and their variation with temperature”, British Journal of Applied Physics, Vol.11, No.6, pp.254-259 (1960).

12) H. Behnken and V. Hauk, "Berechnung der Röntgenographischen Elastizitätskonstanten (REK) des Vielkristalls aus den Einkristalldaten für beliebige Kristallsymmetrie”, Zeitschrift fur Metallkunde, Vol.77, No.9, pp.620-626 (1986).

なお， $\theta_{0}$ は回折角 $71.98^{\circ}$ である. 